\title{
Acanthosis nigricans
}

\section{prof. MUDr. Zdeněk Doležel, CSc., MUDr. Jana Štastná, Ph.D., MUDr. Jan Papež, MUDr. Petra Konečná, Ph.D. Pediatrická klinika LF MU a FN Brno}

Klíčová slova: acanthosis nigricans, obezita, hyperinzulinemie, inzulinová rezistence.

Key words: acanthosis nigricans, obesity, hyperinsulinemia, insulin resistance.

Osmiletý chlapec romského etnika byl prìjat k hospitalizaci pro pravostrannou pleuropneumonii. Od batolecího věku míval častější respirační infekty (jejich frekvence se snížila po provedené adenotomii), ale zejména výraznější hmotnostní prírůstky. Non compliance s doporučením úpravy životosprávy však vedla k dalšímu vzestupu hmotnosti, kdy ve 4. roce života byla 21 kg, $\vee 5$. letech $30 \mathrm{~kg}$ a $\vee 6$. letech $42 \mathrm{~kg}$. Během 4. roku života prodělal komplikovanou bronchitidu (s průkazem viru influenzy typ B) provázenou pravostranným srdečním selháním; od té doby měl trvalou farmakoterapii inhibitorem ACE a při pravidelném kardiologickém sledování neměl hypertenzi a ultrasonografický nález na srdci byl zcela normální.

Při prìjetí ve fyzikálním nálezu dominovaly tyto odchylky: horečka $38,9^{\circ} \mathrm{C}$, hmotnost $63,8 \mathrm{~kg}$ (při tělesné výšce $135 \mathrm{~cm}$ byl BMI $35 \mathrm{~kg} / \mathrm{m}^{2}$, obvod pasu $105 \mathrm{~cm}$ ), oslabené dýchací šelesty nad pravou plicí v rozsahu dolní 1/3 hrudníku a změny na kůži v dorzální oblasti krku, v axilách a v kožních záhybech pod oběma prsy. Kưže v těchto partí́ch byla výrazně černo-hnědě pigmentovaná, papilomatózně ztluštělá, s ložisky hyperkeratózy (obr. 1, 2). Nález na kủži byl hodnocen jako acanthosis nigricans (AN).

AN je afekce, jejiž etiologie je ve sporadických prípadech idiopatická. Daleko častěji je AN doprovodným nálezem řady systémových chorob, jejichž povaha může mít benigní, ale i maligní charakter. Projevy na kưži bývají nejčastěji na krku, v axilách, na čele, v jamkách kubitálních a popliteálních nebo v tříslech; vzácněji může být postižena také sliznice spojivková, oční víčka, rty a oblast peri-genitální/anální. Zcela výjimečně provází AN
Obr. 1. AN na dorzálnístraně krku

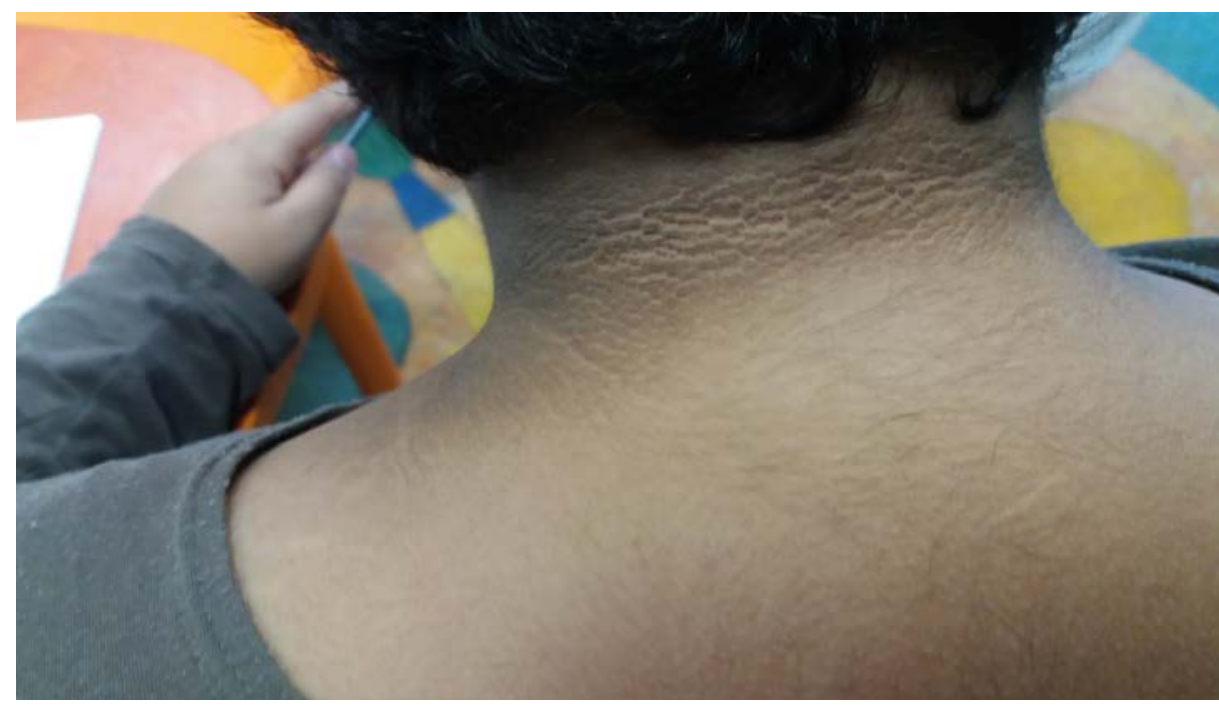

pruritus. AN je nejčastěji asociována s obezitou at již prostou nebo syndromologickou (syndromů spojených s obezitou je dnes identifikováno 79), přitom však vyšší frekvence AN je uváděna u těch obézních, kde dochází k rozvoji inzulinové rezistence nebo metabolického syndromu. Dále bývá AN u některých endokrinopatií - Cushingův syndrom, Addisonova nemoc, hypotyreóza, syndrom polycystických ovarií, diabetes mellitus typ 2. Další skupinu chorob s projevy AN představují autoimunitní nemoci (např. systémový lupus erytematodes, autoimunitní hepatitida, Sjögrenův syndrom). V dětském věku je raritní AN paraneoplastická, která bývá průvodním nálezem adenokarcinomů zažívacího nebo uropoetického traktu. Manifestace AN je uváděna také v souvislosti s léky, které vyvolávají hyperinzulinemii - jde např. o glukokortikoidy, estrogeny, testosteron, inhibitory proteáz. S rozvojem metod molekulární genetiky je popisována spojitost AN s hereditár-
Obr. 2. AN v levé axile a v kožním záhybu pod levým prsem

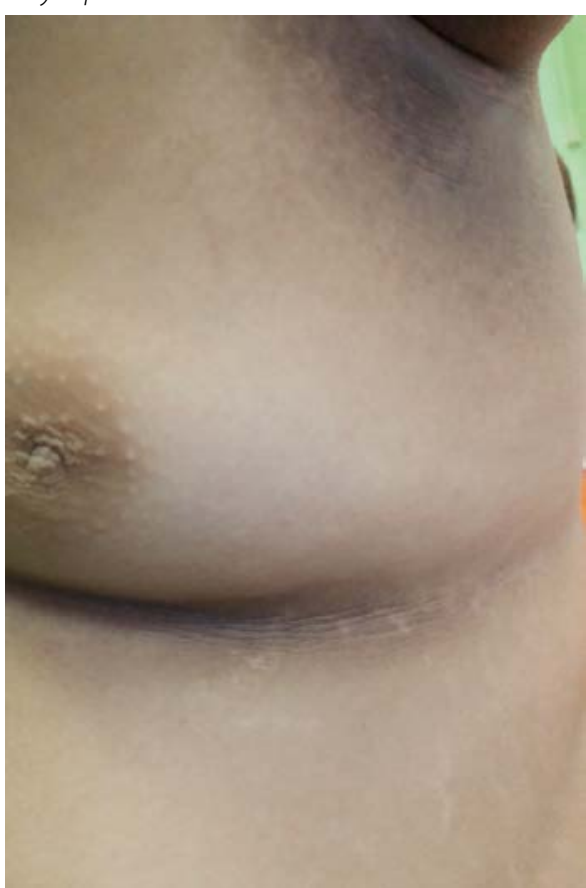

KORESPONDENČNÍ ADRESA AUTORA: prof. MUDr. Zdeněk Doležel, CSc., dolezel.zdenek@fnbrno.cz Pediatrická klinika LF MU a FN Brno

Jihlavská 20, 62500 Brno
Cit. zkr: Pediatr. praxi 2020; 21(1): 54-55

Článek přijat redakcí: 23. 11. 2019

Článek príijat k publikaci: 2. 12. 2019 
ními defekty receptorů pro růstový faktor fibroblastů (Crouzonův syndrom, achondroplazie) nebo s chorobami s poruchou receptorů pro tyrosin kinázu. Z uvedeného je zřejmé, že precizní stanovení diagnózy onemocnění, které je asociováno s AN může být obtižné a vyžaduje obvykle širší spektrum biochemických, ale i genetických vyšetření. Rozhodujícím léčebným opatřením u AN je léčba s AN asociovaného onemocnění. Pokud je terapie úspěšná, pak AN může zcela ustoupit nebo se redukuje rozsah kožních změn. Jestliže projevy AN přetrvávají a představují pro pacienta kosmetickou zátěž, je nezbytná konzultace s dermatologem a využití některých léčebných postupů.

Vzhledem k asociaci AN s tělesným habitem našeho pacienta byly v období rekonvalescence provedeny další biochemické analýzy. Ty vedle dyslipidemie prokázaly hyperinzulinemii, resp. inzulinovou rezistenci, přitom však všechna aktuálně uváděná kritéria metabolického syndromu pro dětský věk hoch nesplňoval.
Na základě těchto výsledků proto probíhají u chlapce doplňující molekulárně genetické analýzy, které by umožnily stanovení presného diagnostického závěru.

Pozn.: pojmenování AN nese „Českou stopu" - prof. Vitězslav Janovský (1847 - 1925) bývá označován za zakladatele české vědecké dermatologie. Společněs S. Pollitzerem má prvenství $\checkmark$ popisu asociace AN s maligními nádory. Podpořeno MZ ČR-RVO (FNBr 65269705)

\section{PIŠEME SPRÁVNĚ ANGLICKY aneb English or Czenglish?}

\section{Je na čase posvítitt si na časy}

\section{Mgr. Aleš Manda}

\section{Centrum pro výuku cizích jazyků Lékařské fakulty UP Olomouc, ales.manda@upol.cz}

\section{V prvním letošním vydání jazykové rubriky se zaměříme na používání některých anglických časů, konkrétně přítomného, předprítomného a minulého, a také na jejich vzájemnou konfrontaci.}

Použití každého z výše uvedených časů pochopitelně implikuje něco jiného:

Most people are not vaccinated... (momentálně a v daném místě);

Most people have not been vaccinated... (zatím k tomu nedošlo, ale může se to změnit);
Most people were not vaccinated... (např. v 80. letech 20. stol.; dnes už může být situace odlišná).

Navíc i tentokrát platí, že budeme-li se striktně držet tvaru českého slovesa, ne vždy se při překladu do angličtiny rozhodneme pro správný čas. Např. větu "Studie se zabývají etiologií tohoto onemocněni" je samožejmě možné přeložit časem prítomným (Studies are investigating the aetiology of this disease), ale pokud by ona věta pokračovala třeba časovým určením „už celá desetiletí", byl by rozhodně na místě čas předprítomný: Studies have investigated the aetiology of this disease for decades.
Podobně větu "Vědci objevili nové genové mutace" můžeme přeložit za použití dvou různých časů: 1) minulý: Researchers identified new gene mutations (in their previous study).

2) předprítomný: Researchers have identified new gene mutations (titulek článku).

Proto na závěr zdůrazněme, že předpřítomný čas je specifický tím, že předpokládá neukončenost popisovaného děje - ten probíhá už po nějakou dobu a je nanejvýš pravděpodobné, že bude pokračovat i nadále (tj. studie zabývající se etiologií určité nemoci), príp. došlo k němu právě ted' a bude mít svoje důsledky (objevení nových genových mutací). 